\title{
A (positive) blot on his record
}

In the early 1970s, Edwin Southern, a young investigator with Peter Walker's group in Edinburgh (University of Edinburgh) was deeply immersed in the problem of characterizing the two $5 S$ ribosomal RNA genes from Xenopus laevis. Cloning technologies were not yet widely available, and techniques for detecting specific DNA sequences were limited. "There were alternatives," recalls Southern, "[but] they were not as good, the results were not as robust and clear-cut, and they were much more elaborate and lengthy."

As is often the case, the breakthrough itself was largely accidental. Southern's work in the Sanger lab had familiarized him with a technique for transferring RNA from cellulose acetate strips to diethylaminoethyl (DEAE) cellulose paper ${ }^{1}$, and research by Sol Spiegelman and David Gillespie had demonstrated the potential of performing hybridization analysis with DNA trapped in nitrocellulose filters' ${ }^{2}$. Southern now had the idea of transferring the DNA content of an agarose gel onto such a filter by floating the gel on top of the filter in a solution of concentrated sodium perchlorate; to his thinking, the solution would soak the filter and dissolve the gel, leaving the DNA behind on the nitrocellulose.

Almost immediately, however, he observed droplets of solution on the upper surface of the gel, indicating that the liquid was rapidly permeating up through the slab. With the work of his predecessors in mind, Southern soon came up with an alternative strategy, relying on the capillary action of transfer buffer for the upward 'blotting through' of DNA from an agarose gel onto a directly apposed nitrocellulose membrane.

The J ournal of Molecular Biology initially rejected Southern's blotting article on the principle that it was 'just' a methods paper, but the technique quickly spread by word of mouth. Investigator Michael Mathews learned it directly from Southern, and then brought it back to the Cold Spring Harbor Laboratory, where he and a colleague, Michael Botchan, each used it to further their research on viral DNA. As such, the method managed to see print months before Southern's article was finally published in 1975 (ref. 3). Says Botchan, "By the time that Ed's paper came out, and this is the ironic thing, it was actually being fairly widely used in the labs that were using restriction enzymes. So the publication was sort of another step, but it wasn't really the first step." Nonetheless, according to Southern, the article remains one of the most-cited articles ever published by the journal ${ }^{4}$.

In the years to come, additional technical developments would further enhance the performance of this technique. To Southern's thinking, the replacement of nitrocellulose membranes with nylon filters was a key improvement ${ }^{5}$. "When they started to use nylon," says Southern, "that introduced the advantage that you could directly blot with an alkaline solution, and that may sound like a fairly small advance, but it actually made quite a big difference."

Southern and Botchan also agree that an essential leap forward came with the improvement of techniques for probe synthesis. "I was using in vivo-labeled RNA," explains Southern, "so we would feed cells with ${ }^{32} \mathrm{P}$ and then isolate their RNA, and that was what we used as probes. This was before the days of cloning, and PCR, and nick translation, so it was limited to what you could make as labeled RNA at this point."

Peter Rigby's development of the nick-translation technique in 1977 made it possible to generate probes with considerably higher specific activity ${ }^{6}$. Botchan's group used this method to create probes, and the improvement was striking, demonstrating that Southern blots could even reveal unique sequences from genomic DNA. "We made very hot probes," says Botchan, "and we used them to actually make a map of genes from SV40 that were single copy - and it was really the single-copy blotting that I think made the method widely used."

Most importantly, Southern's technique became the inspiration for a succession of equally essential transfer protocols for RNA ${ }^{7}$ and proteins ${ }^{8}$, waggishly dubbed 'northern' and 'western' blotting, respectively, in honor of the researcher who started it all.

The Southern blot has remained a virtually indispensable technique for the three decades since, finding applications in genomic mapping, genetic screening and the study of transgenic and mutant animal models, among other things. In recent years, other significant technologies have emerged that have, to varying extents, replaced the blot - particularly with the currently growing interest in large-scale, high-throughput studies. Nonetheless, images of successful blots remain a common sight in the pages of such journals as Nature and Cell, and there seems to be little reason to believe that this technique will fade away any time soon.

\section{Michael Eisenstein}

1. Sanger, F., Brownlee, G.G. \& Barrell, B.G. J. Mol. Biol. 13, 373-398 (1965).

2. Gillespie, D. \& Spiegelman, S. J. Mol. Biol. 12, 829-842 (1965).

3. Southern, E.M. J. Mol. Biol. 98, 503-517 (1975).

4. Southern, E.M. Trends Biochem. Sci. 25, 585-588 (2000).

5. Reed, K.C. \& Mann, D.A. Nucleic Acids Res. 13, 7207-7221 (1985).

6. Rigby, P.W., Dieckmann, M., Rhodes, C., and Berg, P. J. Mol. Biol. 113, 237-251 (1977).

7. Alwine, J.C., Kemp, D.J . \& Stark, G.R. Proc. Natl. Acad. Sci. USA 74, 5350-5354 (1977).

8. Towbin, H., Staehelin, T. \& Gordon, J. Proc. Natl. Acad. Sci. USA 76, 4350-4354 (1979). 